
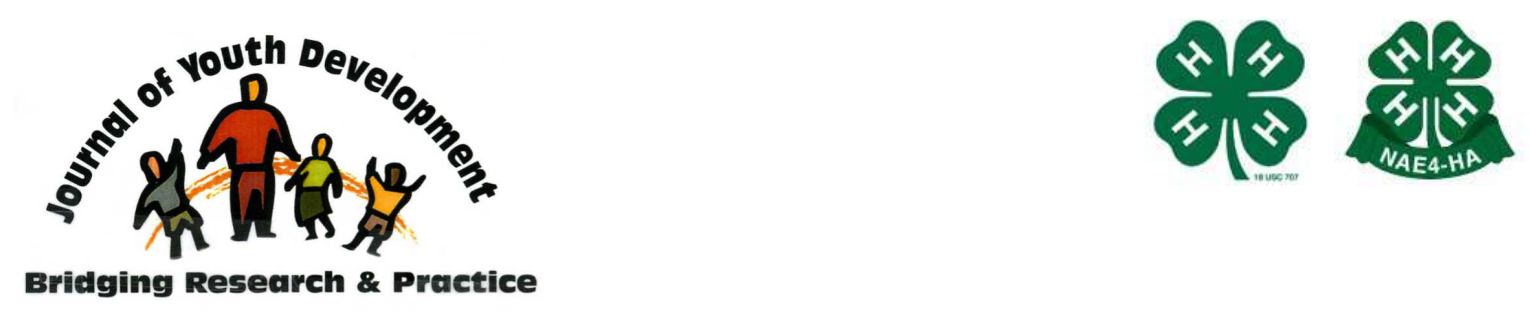

Bridging Research \& Practice

\title{
National Youth Service Day: A Youth Development Strategy
}

Silvia Blitzer Golombek, Ph.D.

Youth Service America

Washington, DC

sgolombek@ysa.org 


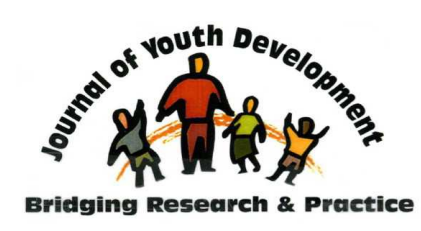

Volume 1, Number 1, Spring 2006

\section{JOURNAL OF YOUTH DEVELOPMENT \\ bridging research and practice}

Article 0101PA002

\title{
National Youth Service Day: A Youth Development Strategy
}

\author{
Silvia Blitzer Golombek \\ Youth Service America
}

\begin{abstract}
A growing number of studies show connections between youth participation in service and service-learning opportunities and positive behavior outcomes. Building on this data, the article presents National Youth Service Day (NYSD) as a program that can be incorporated into ongoing activities to enhance youth development goals. The paper describes the program's components: building a network of support organizations, offering project planning grants, providing service-learning materials, and developing a media and advocacy campaign. Examples of NYSD projects show how project planners are using the program to learn and practice academic and nonacademic skills. A review of evaluations to date indicates the program is annually increasing its output measures. Participants' responses show that the program is also contributing to positive behavioral changes, in particular related to young people's increasing awareness about specific community issues and their own competency in addressing them.
\end{abstract}

\section{Introduction}

The meaningful engagement of young people in service and service-learning activities is increasingly seen as a building block of positive youth development. Research studies support the connection between opportunities for youth to contribute their skills through service and positive behavior outcomes including a sense of belonging, higher academic achievement, increased self-esteem and a reduction in harmful activities (Scales, P., \& Roehlkepartain, E. 2004; RMC Corporation, 2005). Data from the Independent Sector also show that engaging 
children and youth in service at an early age leads to the internalization of philanthropic attitudes that lasts into adulthood and is passed on to the next generation (Toppe, C., \& Golombek, S., 2002).

Building on the relationship between service and positive behavioral outcomes, Youth Service America (YSA) has developed and implemented programs and resources to increase the quality and quantity of opportunities for all youth to serve. This includes youth traditionally perceived as care recipients rather than care-givers such as youth with disabilities, children living in poor socioeconomic contexts, in the juvenile justice system, and others.

Founded eighteen years ago, National Youth Service Day (NYSD) is YSA's oldest program. NYSD has been renamed National and Global because of its international expansion as the largest service event in the world reaching millions of youth and adults every year (Youth Service America, 2005a). During a designated weekend every April and the months leading up to the event, youth plan and lead service and service-learning projects to address prevalent needs in their communities. Youth projects have included tutoring recent immigrants in English skills, collecting food and clothing for those in need, organizing social events for the elderly and restoring historic landmarks in their cities. The campaign, primarily sponsored by the State Farm Foundation Companies, serves as a spotlight for the positive roles youth play in their schools, youth groups, and communities year-round. Since 2000, the program has expanded outside the United States reaching more than 100 countries celebrating Global Youth Service Day, by adapting the NYSD model to other cultures and contexts (Youth Service America, 2005b).

Youth Service America believes that a concerted effort among multiple stakeholders to encourage and support young people's participation in activities for the public good, will lead to stronger, healthier and more democratic communities - in essence, a culture where youth are engaged citizens. This belief is reflected in YSA's theory of change which states assumptions regarding programs and expected results. Specifically formulated for National Youth Service Day, the YSA's theory of change states the following:

If we lead in a coordinated campaign to engage youth as leaders of service projects by involving the media and policymakers and by providing programmatic support, written tools, and grants, then we will create an enabling environment where young people are recognized as leaders and positive role models in the eyes of adults, the media and policy makers.

\section{National Youth Service Day - More than a Day of Service}

Based on the statement above, the program is structured to integrate the following key components of what YSA has learned works to support positive outcomes for youth. (Complete information about the program, how to participate and access its resources can be found at www.ysa.org/nysd):

a) Convening and building the capacity of a network of organizations: YSA works in the field through a coalition of fifty National Youth Service Day lead agencies and over 100 national partners that mobilize thousands of youth and entire communities and states for the event (the 2006 lead agencies and partners are listed in www.ysa.org/nysd). 
The lead agencies and partners receive YSA support in different ways, including grants, materials, targeted trainings, and resources to enhance their communications and outreach strategies to involve youth in service projects. This infrastructure of local contacts and organizational support are invaluable assets to young volunteers, schools and organizations that can access them for ideas and contacts, guidance and also to join their larger projects.

b) Educational tools and materials: National Youth Service Day participants have access to free curriculum guides, tool kits, educational posters and tip sheets that apply a service-learning model to teaching project management skills. These materials, available electronically and in hard-copy, provide information, activities, examples, and reflection exercises that take the reader through a step-by-step process of organizing a service project including community mapping, goal setting, partnership development, assigning and monitoring responsibilities, budgeting and other key project management tasks. They also include hundreds of project ideas that youth development practitioners can easily apply to their needs.

c) Grants and incentives: A significant component of YSA's programming are grants provided to youth and adults to support their project planning efforts. Financial incentives ranging from $\$ 500$ to $\$ 1,000$ convey the message that youth's ideas to improve their communities are important and require the means to be implemented. Because service-learning is shown to improve academic achievement, strengthen critical thinking and sense of competency, and engage students to their community, YSA promotes a service-learning approach in the projects it funds (RMC Corporation, 2005). Grant forms and announcements are disseminated widely through list serves, press releases, and through www.ysa.org/awards. Several YSA partners offer grants to support National Youth Service Day projects, substantially multiplying the financial resources available for the program.

d) Public awareness and advocacy campaign: Targeted approaches to the media are key elements of a public education campaign. As it shapes public opinion, it is critical to provide the media with concrete examples of young people's assets and their social contributions. YSA provides project organizers with press release templates, materials, and training to help them pitch their projects to reporters. YSA itself conducts a massive national media campaign to highlight the role of youth as resources on National Youth Service Day and year round.

Educating public officials is also integral to the overall strategy. If decision-makers are made aware of the skills and time youth contribute to improving their communities, they will be more open to interacting with them as a key constituency and integrating youth in decisions on relevant matters (109th Congress S.Res.105). YSA's experience shows that the encouragement to invite public officials to service projects has led to a greater awareness among youth and their adult allies about the importance of working through multi-sector partnerships to achieve results.

Promoting a culture of youth engagement is not a single weekend proposition; on the contrary, National Youth Service Day is a program strategy implemented year-round through the consistent dissemination of public messages, tools, and capacity building resources to strengthen the field. For that reason, it is not conceived as an "add-on" program for organizations, but rather as an opportunity that youth development practitioners can tap into to enhance ongoing activities. 


\section{The "faces" of National Youth Service Day}

National Youth Service Day comes to life through the children, youth, and adults that use its framework to make their communities better. In all cases, project organizers throughout the country are encouraged to contact lead agencies and national partners for additional resources and advice. Projects have free access to templates and guides to contact media and public officials, are eligible for grants, and receive multiple forms of technical assistance and support for their efforts. Since youth are encouraged to determine which community needs they will address, there is no limit to the range of projects organized for any given year.

For example, members of the River Legacy's Foundation Junior Naturalists Club used the National Youth Service Day 2005 framework to increase the percentage of homes participating in the city recycling program. They went door-to-door handing out flyers to encourage neighbors to recycle and handed out bins to 42 households. The Junior Naturalists monitored the recycling rates for several weeks and measured a $62 \%$ increase of homes participating in the city's recycling program. On National Youth Service Day 2005, the youth hosted a reception to present their project results to residents, city officials, foundation board members, and staff. Given the success of the campaign, The River Legacy Foundation now plans to recruit and engage more youth to lead the effort.

A different type of project took place in Lauderdale, Florida, where The School Board of Broward County and the 160 ninth graders who participate in the Summer Transitions program (a year round school for at-risk youth), conducted a service-learning project to benefit their community. The school, the students, Children's Services Council, and the Internal Revenue Service partnered for a community marketing campaign about the Earned Income Tax Credit (EITC). To prepare for the event, students learned about the EITC and marketing and communications techniques. On the evening of April 15, 2005, National Youth Service Day, youth made presentations and offered promotional materials to educate local community residents and their parents about the tax program.

Confirming that all children can serve, students from Blossom Montessori School for the Deaf established a relationship with Pinellas Habitat for Humanity, Florida. While distributing cold water, snacks, and hand-written thank you notes to the workers on site, the children learned about the volunteers' favorite childhood books. That led to a year-round project by which the students sponsored an ongoing book-drive and donated a new bookshelf filled with ageappropriate books for each new Habitat home built in the Pinellas County area for the year 2005.

Another example of the possibilities created by NYSD is the project organized by a 4th grade class at Community Academy Public Charter School in Washington, DC, that decided to host a Foster Care and Adoption Carnival at their school. They organized fun games and activities for foster care kids and set up an area for foster parents and community adults to learn child safety and nutrition issues as well as how to become a foster care or adoptive parent. The students worked with the local community agencies and businesses, and involved government officials to provide a full day of activities and information sessions that resulted in five foster children matched with adoptive parents. The planning and implementation of the project was used as the vehicle for the students to practice business writing, learn how to fill out a grant application, 
understand public officials' duties, and gain information about how the foster care program works.

Thousands of similar projects are carried out through the process and the momentum created by National Youth Service Day, confirming the program's potential to engage everyone - young children, those with disabilities, youth from disadvantaged backgrounds, community representatives, businesses and public officials in addressing social needs.

\section{The Impact of National Youth Service Day}

While a rigorous impact assessment of National Youth Service Day has not been conducted, cumulative evidence indicates positive developments as measured by the consistent and marked increase in numbers of volunteer participation, partner involvement, grants disbursed, public officials' recognition, and media coverage.

In 2005, 115 National Partners (including 8 Federal Agencies) promoted NYSD through their networks of local chapters and affiliates (compared to 93 partners in 2004 and 63 Partners in 2003), representing a combined constituency of 60 million. Fifty Lead Agencies engaged close to 160,000 volunteers, up from 112,000 in 2004 and 85,000 in 2003, who contributed an estimated $\$ 10$ million to the economy through their service. More than 768 planning grants totaling $\$ 529,000$ were offered in support of service projects around the country. And from a media perspective, the coverage generated over 728 million media impressions in the United States alone.

Beyond the numbers, other indicators point to important behavioral and cultural changes. Project evaluations submitted indicate the young volunteers learn academic and non-academic skills such as how to create and manage a budget, phone etiquette, time management, problem-solving and teamwork.

Other results point to community agencies' growing confidence and eagerness to work with youth and to acknowledge young people's skills and contributions. A key indicator of the program's impact is the young volunteers' realization that they do have power to improve their communities. Participants express that the process of planning a National Youth Service Day project gives youth an opportunity to address local issues that concern them and to work alongside other community partners to make a difference. Along the way, youth feel inspired by the notion that they are part of something bigger: young people across the country and around the world creating positive change.

As a strategy for youth development, National Youth Service Day facilitates the implementation of the core assets young people need to reach their potential. In the process of planning and organizing a meaningful project, youth are encouraged to partner with caring adults, use and create safe places for themselves and their peers, develop marketable skills through servicelearning approaches, engage in healthy behaviors, and of course serve. 


\section{References}

RMC Research Corporation. (2005). Impacts of Service-Learning on Participating K-12 Students; Retrieved January 25, 2006 from Service Learning Clearinghouse:

http://servicelearning.org/resources/fact sheets/k-12 facts/impacts/index.php

Scales, P., \& Roehlkepartain, E. (2004). Community Service and Service Learning in U.S. Public Schools; Findings from a National Survey, MN:NYLC.

Toppe, C., \& Golombek, S. (2002). Engaging Youth in Lifelong Service. Washington, DC: Independent Sector.

United States Senate. $109^{\text {th }}$ Congress. (2005). Senate Resolution 105. Retrieved January 24, 2006, from: http://frwebgate.access.gpo.gov/cgi-

bin/getdoc.cgi?dbname=109 cong bills\&docid=f:sr105ats.txt.pdf

Youth Service America. (2005a). National Youth Service Day Final Report 2005, retrieved January 24, 2006 from Youth Service America http://www.ysa.org/pdffiles/nysd/2005/General rpt NYSD 2005.pdf

Youth Service America. (2005b). Global Youth Service Day Final Report 2005. Retrieved January 24, 2006 from www.ysa.org/pdffiles/gysd/GYSD05 FinalReport v3d.pdf

(C) Copyright of Journal of Youth Development Bridging Research and Practice. Content may not be copied or emailed to multiple sites or posted to a listserv without copyright holder's express written permission. Contact Editor at: patricia.dawson@oregonstate.edu for details. However, users may print, download or email articles for individual use.

ISSN 2325-4009 (Print); ISSN 2325-4017 (Online) 